\title{
COGNITIVE LINGVISTICS VERSUS GENERATIVE LINGVISTICS
}

\section{Mizetska V. Y., Zubov M. I.}

\section{INTRODUCTION}

The paper is devoted to the problem of cognitive linguistics (CL) and generative linguistics (GL) correlation in general methodological and linguophilosophical aspects. Different sides of the item were regarded in a number of works. ${ }^{1}$

We believe that it is time to generalize and systematize the information concerned.

In the process of investigation there was used a comparative analysis, various approaches and points of view being considered (see the references). ${ }^{2}$

The given work is based on the analytical observation of the papers written by the representatives of these two linguistic paradigms.

Cognitive linguistics acquired its official status in 1989 (Duisburg), when there was held the first international conference on CL. The participants decided to found the International Cognitive Linguistic Association (ICLA) and the Journal « Cognitive Linguistics» (1990). ${ }^{3}$

\section{Birth and Development of Cognitive Linguistics}

Many scholars associate the birth of the cognitive linguistics with the publication of the well- known book by J. Miller and B. Johnson - Laird “ Language and Perception” (1976).

But in reality CL appeared earlier. The end of the XX c. is not the period of birth, but the period of development, the time of numerous publications concerning CL.

CL nowadays is not a unificated theory, but the whole number of various theories (J. Lakoff, R. Jackendoff, R. Langacker, Ch. Fillmore, S. Rosch, J.Fauconnier, etc).

1 Баранов А.Н., Добровольский Д.О. Постулаты когнитивной лингвистики. Известия РАН. Сер. лит. и языка. 1997. Т. 56.№ 1;

${ }^{2}$ Кибрик А.А. Когнитивные исследования по дискурсу. Вопросы языкознания, 1994. № 5;

${ }^{3}$ Кубрякова Е.С. Размышление о судьбах когнитивной лингвистики на рубеже веков. Вопросы филологии, 2001.№ 1(7). и др. 
A great number of theoretical constructions and terms, a wide spectrum of linguistic phenomena, usage of nations borrowed from the other disciplines, original approaches to the analysis of the material, - all these factors set up barriers for the accurate definition of the CL subject.

Even the notion of category is not treated identically by different cognitivists.

There are two main alternative theories of category: one is classical and it goes back to the times of Aristotle, the other one -- prototypical. It was formed in the 1970s and based on the research of the American cognitive psychologist E. Rosch.

The main statements of the Aristotle's notion of category are as follows:

- categories are abstract containers with distinct borders;

- members of the category have a set of substantial common qualities which are a necessary and sufficient condition of membership in this particular category:

- members of the category have equal status within the category.

The experiments of E. Rosch refuted the idea of the equal status of all members of the category. Rosch introduced the notions of the centre, periphery and the prototype of the category. She stated that the typical representative of the category is its best example. This pattern lies in the centre of the category and forms the prototype of the given category. The least typical members of the category occupy its periphery ${ }^{4}$.

Another contribution to the cognitivistics of E. Rosch is the introduction of the so - called category of the basic level.

This cognitive category is characterized by the following language qualities:

- short, highly frequent and stylistically neutral words which are learned in early childhood;

- the words of the basic category are words which occupy some middle level in the taxonomic hierarchy. In the triad " furniture - table desk" the word 'table'is localized on the basic level.

As to the categories of the lower level they are often actualized with the help of the word combinations built on the model 'the generic nomination + qualifier', for example, Persian cat; billiard table; winter coat, etc.

Nomination of the higher level notions is known for great number of uncountable nouns in different languages (furniture) and compositional words (electroappliances).

\footnotetext{
${ }^{4}$ See in detail : Rosch E. Natural Categories. Cognitive Psyhology. 1973. № 4.
} 
In some languages the categories of higher rank do not exist. For example, in the English language there is a special word ' sibling', while in Russian there is not a special word for the notion ' brothers and sisters'.

The characteristic quality of the categories of higher rank in the German language is a great number of nouns in the neuter gender (Tier, Obst, Gemüse, Metall) while on the lower levels the words in the feminine and masculine gender prevail when denoting concrete kinds of animals, fruit, vegetables, etc.

But the majority of the scholars agree with the following general definition of Cognitive Linguistics: Cognitive Linguistics studies production, transmission, storage and retranslation of information.

Let us analyze the main principles of CL, which in many aspects differ from the principles of Generative Grammar:

1) CL is based on the holistic approach to the interpretation of the language capacity, processes of perception and speech production in controversy with the modular approach supported by the adherents to the generative grammar.

This approach is based on the analogy between the information processing of the human being's mind and the computer. The basic idea consists in the following: in the psycho-verbal mechanisms there exists a number of independent and autonomous working systems of information processing called modules.

The decision of every module after the processing of the particular information is transmitted to the system (central processor), where it correlates with the information received from the other modules.

The foundation of the modular theory belongs to J. Fodor ${ }^{5}$. He defined the module as the informatively - encapsulated computing (calculating) system.

Any module can be presented as a special computer with its own basis of data under the following conditions:

a) for the operation of the computer there is used only its own basis of data plus the characteristics of the input stimulation, acting at the given moment;

b) at least part of the information, accessible to the other cognitive processes, is not accessible to that particular module ${ }^{6}$.

Thus, the modules are relatively isolated units. They work independently according to their own algorithms in the automatic regime, each with its own material, including the linguistic one.

\footnotetext{
${ }^{5}$ Fodor. J. The Mind Does not Work that Way: Camb. (MA), 2001.

${ }^{6}$ Jackendoff .R. Semantics and Cognition. Cam. (Man /1993)
} 
But the cognitivists do not accept the idea of the modular organization of the mechanisms of information processing. They are adherents to the connectionism.

Connective approach is associated with the names of Dreifus, Rumelhart, Lakoff. The basic idea of connectionism - is the parallelism of data processing received from different sources in the time of interaction of all the systems. Hence, another term for this approach, - interactional.

This approach provides the situation when all the meaning forms are represented as network structures. The network consists of the nodes and connections between them. Hence, the key name of this theory, connectionism.

Thus, one of the postulates of CL is the non - modular character of the language. In this respect cognitivism radically differs from the generative grammar. We suppose that refusal of the modular ideas reduces possibility of CL to obtain objective data as it accepts only the idea of connectionism.

We cannot but agree with V. Kasevich, who believes that both modular and non- modular structures are used by the mental apparatus and that ignorance of modularity deprives CL of research object ${ }^{7}$.

Nowadays the scholars develop the idea of the hybrid system of the speech information: coordination of the connectional networks and modular systems ${ }^{8}$.

One of the original versions of the language and mental activities correlation is put forward by D. Bickerton ${ }^{9}$.

He believes that there are two types of mental activity:

1) mental activity on-line. It is a combination of channels through which the human being interacts, comes into contact with the objects of the environment;

2) mental activity off-line, which suggests the operations of the brain. In this case there is not a direct connection with the processes outside.

In on-line cases every stage of mental activity launches the next one. In off-line mechanisms the stages of mental activity do not rigorously follow one another. Bickerton gives such an example: if somebody utters the phrase where the red roses are mentioned, a person may first think of roses, then think of the red color, or vice versa, or even simultaneously.

\footnotetext{
${ }^{7}$ Касевич В.Б. Когнитивная лингвистика. В поисках идентичности. Москва, 2013 . С. 113.

${ }^{8}$ Цепцов В.А. От критики коннекционизма к гибридным системам обработки информации. Познание. Общество. Развитие. Москва. 1996.

${ }^{9}$ See in detail: Bickerton D. Language Evolution: a Brief Guide for Linguists. Lingua. 2007. № 117(3).
} 
D. Bickerton believes that in the brain there are neither images nor words. The thoughts do not exist in the brain either. He thinks that there is only a constant stream of neurons, pulsation of spikes, movement of impulses, each one having its own direction.

In general D. Bickerton believes that meditation, mental activities in the forms of evolution did not precede the birth of speech though many scientists think that mental activities are primary while speech is only derivative. The problem of the primary nature of speech or thinking is debatable.

T. Chernigovskaya believes that the brain and computer are not identical though the so - called computer metaphor is very popular with overwhelming majority of the scientists.

Chernigovskaya believes that the computer metaphor irrelevancy is stipulated by the specific qualities of the mind. She enumerates the following specific characteristics of the human being's mind operation:

- a very important role of the context, possibility of multiple treatment of the data, facts and events;

- the use of different algorithms and their redundancy, occasional finding of the phenomena which were not the object of the special search;

- unprognostication and unexpectedness of the results;

- inaccuracy, approximateness of the descriptions;

- multiplicity of the mental activity types defined by culture and the task;

- humorous utterances production which computer is not able to generate.

Nowadays the scientists are able to model only the computational activity of the left hemisphere. The right hemisphere is the mechanism which provides the processes connected with intuition, individual decisions and associations. Scientists are not able to properly model this unpredictable mechanism of the right hemisphere.

2) In CL linguistic analysis is not reduced to the description of the linguistic behaviour, but covers the corresponding mental states and processes.

As to the speakers whose languages have a complicated combination of the consonants and vowels their left hemisphere is usually engaged in perception of consonants which are different from the vowels at most.

The right hemisphere participates in the perception of vowels and some sounds which are intermediate between the vowels and consonants, for example, glides of the English type [ w] or the Russian initial 
phoneme [ j] in the word йод (iodine). All these peculiarities are characteristic of the speech and mind of the Europeans.

But the research of some scholars showed that it is not so in the Japanese language. According to data obtained by them the vowels belong not to the zone of the right hemisphere as is the case with the Indoeuropeans but are controlled by the left hemisphere. This fact made some scientists suppose that the brain of the Japanese people works in the way different from that of the Europeans. But this supposition seems to be too bold / daring and is not shared by many researchers.

As to the hieroglyphic languages, hieroglyphs are discerned by the right hemisphere. But after their acception they are transmitted through the interhemispheric channels to the left hemisphere where they are registered and transformed into the verbal code.

Experiments showed, that in the right hemisphere the sense of words is stored in the form which does not depend on the sound image.

It is known that the Japanese use both hieroglyphic and two syllabic alphabets which register the sounding of the words, first of all, proper names and borrowings. When the left hemisphere is swiched off there are problems with the syllabic writing, but there are not any problems with hieroglyphic script which works in the usual regime.

The right hemisphere perceives hieroglyphs as images while the left hemisphere perceives them as elements of the code.

Thus, hieroglyphs can be perceived and reproduced not only as the whole but as the ensemble consisting of the set elements. The right hemisphere discerns new hieroglyphs while the left one discerns the well - known hieroglyphs and their combinations.

In general in hieroglyphic cultures there is the inclination to the continuity (the right hemisphere activities).

It was counted up that the quantity of information which has one Japanese hieroglyph is 500 times more than the quantity of information which contains one English letter. This peculiarity of the hieroglyphs can be connected with the operations of the right hemisphere which looks like a specific holographic apparatus.

It is known that generative grammar is concentrated on the language structures and does not rely upon neurophysiologic research. Generative grammar does not try to analyze the hemispheric peculiarities of speech production and speech perception.

3) CL proclaims the close connection of the language meaning with the psychic system of the human being, while GL reduces the possibility 
of the algorithmic approach to the description of the language. Cognitivists are for the close relations of linguistics and biology ${ }^{10}$, while in generative grammar the connection of linguistics with logic and mathematics is accentuated.

As is known, transformational analysis of N. Chomsky is based on the strict logic (al) operations, aimed at the working-out of the corresponding algorithms of necessary transformations.

4) CL refers to the so - called anthropocentric paradigm when the human factor comes to the fore. Anthropocentrism in CL flows from the postulate which states the connection of the language with cognition, mentality and phychic features of the human being.

Cognitivists believe that anthropocentricity runs through the language and reveals itself in a wide spectrum of the language structures. The subject of perception, speech, production and observation is taken into account in all the investigations irrespective of the individual theoretical approach of different scholars.

Generativists do not consider the anthropocentric factors as the substantial ones.

Generative grammar was always concentrated on the inner mechanisms of the language structures. The generativists believe that the subjective factor only hinders the creation of the objective picture of language elements interaction.

5) CL stresses the central role of the physical experience of interaction with the social environment in its cognitive system. In connection with such an idea they put forward the thesis that mental activity is " embodied», that is closely connected with the body of the human being, his / her anatomic and physiological peculiarities, perceptive and motor experience.

Generativists do not think that somatic peculiarities are an important factor which influences the speech production. It reduces all the diversity of the speech activity to the pure schemes.

We believe that it is one of the main drawbacks of generative grammar which prepares the language ignoring the figure of the speaker as its generator.

6) CL demands for the subjectivization of linguistic investigations while the generativists postulate the objective description of the language based on the language competence of some common speaker, " functioning» in some neutral social environment.

\footnotetext{
${ }^{10}$ Miller G.A., Johnson - Laird P.N. Language and Perception. Cam ( Mass), 1976.
} 
Thus, CL proclaims the principle of serious subjectivization of language activities. This fact stipulates the wide usage of the extralinguistic information: facts concerning the participants to the communication, social characteristics, psychological peculiarities, communicative intention, background, experience, emotional state, etc. Cognitivists also accentuated the attention on the referential situation, that is the place, time, social atmosphere and the status characteristics of the communicators.

Generativists ignore all these concrete circumstances and conditions, under which the communication occurs, they exclude the social aspect from the observation. Thus, generativists are representatives of the structural paradigm which dominated in the middle of the XX c.

7) The tendency towards explanation is one of the main features of CL. This trend contradicts the idea of generativists who believe that the task of the linguist is not explanation but only registration of the facts. They think that interpretation causes subjectivization and distortion of the real picture of the language mechanisms.

8) CL proclaims the maximum openness and readiness to incorporate the information from different fields of knowledge. Generative grammar is concentrated on the inner qualities of the language, its functions in the more hermetic conditions.

Cognitive linguists profess the principle of the cognitive obligation, that is promise to rely upon the results of the other sciences.

We should admit that one of the weak spots of CL is the absence of the independent methodological basis. The main method of data collection is introspection, though nowadays many cognitivists began to apply empiric (al) methods, - both experimental and corpus ones.

Now CL rests on many results of neurophysiology. The borders between CL and neurolinguistics and phycholinguistics become more and more diffuse.

Generativists in this respect are more consistent. They use their transformational methods irrespective of the individual approaches to the language studies.

\section{The Neuropsychological Aspect of the Cognitive Linguistics}

Cognitivists support the research of the neuropsychologists and neurophysiologists in the field of hemispheric functions which gave a lot of data to be used for the analysis of the mental mechanisms connected with speech perception and production. 
The left hemisphere accepts information discretely which allows it to control speech activities in their symbol designations - words, hieroglyphs, figures, etc. It restores the picture of events partially. Due to this ability the left hemisphere easily carries out the metonymic operations, when the part becomes equal to the whole. It gives possibility to use for the latter different nomens (nominants) denoting parts of the particular whole which later may pass from the sphere of appellatives into the sphere of proper names : a girl in a red cap $\rightarrow$ red cap $\rightarrow$ Red Cap.

Judging by the data obtained recently, the spatial and visual picture in general is created by the right hemisphere. The left hemisphere singles out from the spatial picture separate details, while the right one gives the whole picture.

The left hemisphere may be called metonymic, while the right one metaphorical as it works on the principle of analogy.

The left hemisphere analyzes and synthesizes sentences using all the grammatical information and the lexical one with which it is connected.

The front part of the speech zone of the left hemisphere is responsible for the grammatical structures and the words which are connected with them, while the backward part is responsible for the nomination of separate objects.

We cannot say that the nominative function is not performed by the right hemisphere. But first of all it is responsible for the concrete semantics and not for the abstract notions which are controlled by the left hemisphere.

The frontal parts of both hemispheres are responsible for the most complicated grammar (in case of the left hemisphere) or semantic (in case of the right hemisphere) relations, the backward ones are responsible for the relatively simple connections.

It is the right hemisphere which gives possibility to interpret the sense of words. The right hemisphere is concentrated on the denotatum while the left hemisphere is concentrated on the significant. V.V. Ivanov believes that concrete semantic information concerning the outer world, which is given in encyclopedias, reference books and defining dictionaries, is mostly stored in the right hemisphere ${ }^{11}$.

The speech zones of the left hemisphere are specialized on the phonemic analysis and synthesis. They deal with separate, discrete units

11 Иванов В.В. Нечет и чет: ассиметрия мозга и знаковых систем / Иванов В.В. Избранные работы. Т. 1. С. 431. 
into which (the) speech is divided. The separate unit is not the basic one for the right hemisphere but the phonological image of the whole word.

These and other neuropsychological experiments help cognitive linguistics to explain many phenomena. Generativists who ignore this sphere of investigation are deprived of the possibility to thoroughly explain all the processes operations and to find the causes of particular transformations of the deep structures into the surface ones.

9) Due to the results of neuropsychgiological experiments concerning mental activities cognitologists managed to convincingly prove the unfoundednesss of some statement of the generativists.

The scientists obtained the unexpected results as to the activities of the left hemisphere which, as the neurophysiologists stated, is responsible for the language structures and the logic part of the utterance.

The preliminary investigation shows that the left hemisphere easily copes with syllogisms. But recent investigations gave the unexpected result: the left hemisphere copes with the complicated structures and does not cope with some simple ones.

On the basis of these experiments of the neurologists cognitivists antigenerativists put under doubt one of the main statements of generative grammar - the priority of the active structures. The generativists always stated that active constructions are primary in terms of speech generation while passive constructions are secondary: the latter are the result of the certain transformational operations. Generativists have a sceptical attitude to the results of the neurologists. The neurologists delivered a strong blow to the generative ideas as they discovered some new functions of the left hemisphere. But the problem of priority of the active or passive constructions today is debatable. The further investigation will help to dot all "i's". follows:

The peculiarities of the hemisphere functions recently found are as

1) criterion 1 - the type of the syllabic structure of the language . There is an opinion, that the speech centres which work with the languages having the close syllable (the majority of the languages) are mainly concentrated in the left hemisphere while the speech centres working with the open syllables (Japanese, Polynesian languages) are localized in the right hemisphere;

2) criterion 2 - the correlation of the alphabetical and hieroglyphic systems of writing. It is supposed now that the language with the alphabetical system of writing is more closely connected with the left 
hemisphere, while the hieroglyphic systems are more closely connected with the right hemisphere;

3) criterion 3 - the direction of writing. The scholars put forward the hypothesis that the languages with the direction of writing from the left to the right are more closely connected with the left hemisphere and the languages with the direction of writing from the right to the left are connected with the right hemisphere;

4)criterion 4 - orientation to the type of mental activities. The experiments made the scientists believe that the languages oriented to the European logical type of mentality are more closely connected with the left hemisphere while the languages oriented to the mythopoetic tradition are closely connected with the right hemisphere which is sometimes called imaginary.

The problem of the mental lexicon and its language representation is one of the widely discussed one at the end of the XX c. and the beginning of the XXI c.

In scientific literature there are singled out two contradictory approaches: two - system one (Markus, Pinker, Ullman) and one - system approach in its connectionist version (Rumelhart, Plunkett, Marchman) or in its network version(Bybee).

The supporter of the two - system approach (generalitivists) postulate the independent mechanism of regular and irregular morphological forms production, particularly verbs.

Generativists believe that regular verbs are stipulated by the rules, that they are produced according to the rules by the speaker while irregular ones are retrieved from the memory automatically.

The one - system approach is functional. It is based on the idea of the single mechanism of form production and appreciates the lexical and semantic relations. Its supporters believe that in the brain which looks like one neuron network there are not any rules. They state that there is not a principal difference in the store, transformation and retrieval of the regular and irregular morphological forms.

But experiments in this field give some contradictory results. The first experiments were based on the Germanic languages but the data obtained gave favour to neither of the principles.

But when some other languages were analysed (Scandinavian, Italian, French, Spanish, Polish, Russian) the one - system approach turned out to be more convincing. 
T. Chernigovskaya believes that the retrieval mechanism of the regular and irregular verbs requires further research. First of all it is a problem to describe these mechanisms for the languages which have a ramified morphological system. ${ }^{12}$

The recent research showed that the speech zones of the brain practically react identically to different peculiarities typical of different parts of speech.

This fact gives possibility to suppose that semantics here dominates over the grammatical meaning. We believe that this phenomenon explains active conversive processes, transformation of the words of one part of speech into another. It also can explain the structural and morphological variation of different models for expressing one and the same idea, notion or a situation.

Thus, neurology and psychology help cognitive linguistics to realize and explain a number of language phenomena which remain inexplicable, when generativists apply the purely structural approach to the languages studies.

\section{CONCLUSIONS}

On the basis of the analysis we may draw the following conclusions:

1) cognitive linguistics and generative grammar have their strong and weak spots;

2) the strong sides of cognitivism are as follows:

a) cooperation with neurophysiological investigations which helps to deeper understand the mechanism of information perception, storage and transmission;

b) consideration of the subjective factor without which it is impossible to represent the main mechanisms of communication;

c) cooperation with other branches of science;

3) the strong sides of generative grammar are as follows:

a) in-depth structural analysis of the language;

b) study of the speech production processes, which suggests the number of transformational procedures fulfilled by the mind;

c)an accurate definition of the object and tasks of the research ;

4) the weak spots of cognitive linguistics are: basis;

a)absence of the universal theoretical foundation and methodological

12 Черниговская Т.В. Чеширская улыбка кота Шрёдингера: язык и сознание. Москва: Языки славянской культуры, 2013.448 с. 
b) negation of the modular mechanisms of perception and information processing;

c) absence of the exact/ accurate terminology, application of different terms for denoting one and the same phenomenon;

5) the weak spots of generative grammar are as follows:

a) ignoring of the semantic aspect of the speech;

b) exclusion of the social factor and the figure of the speech producer / generator from the analysis and observation of the verbal and mental processes;

6) CL exists in the frames of anthropocentric paradigm while generative grammar is the key link in the structural paradigm. The latter lost its positions giving way to cognitive linguistics in the XX - XXI c.

\section{SUMMARY}

The article is dedicated to the correlation of cognitive linguistics and generative grammar. These branches of linguistics have some principle differences. Cognitivists believe that speech production and its perception are based on the connective systems and networks while generative grammar insists on the modular principles of speech production and perception.

Cognitive linguists state that the mental activity is closely connected with the body functions of the human being while generative grammar is concentrated on the inner qualities of the language structures and excludes from observation the figure of the speech generator and his / her individual features. Cognitive linguistics takes into account the achievements of neuropsychology and other sciences while generative grammar works only within the frame of pure linguistics. The investigation of the hemisphere operations helps cognitive linguistics to explain many mental and verbal phenomena, semantic peculiarities while generative grammar ignores the semantic aspects.

Cognitive linguistics has its drawbacks. Its terminological apparatus requires further specification and its methodological basis is not unificated. Nevertheless, cognitive linguistics dynamically develops while generative grammar went to the background of linguistic researches. 


\section{REFERENCES}

1. Баранов А.Н., Добровольский Д.О. Постулаты когнитивной лингвистики. Известия РАН. Сер лит. и языка. 1997. Т. 56. № 1.

2. Иванов В.В. Нечет и чет: ассиметрия мозга и динамика знаковых систем. Иванов В.В. Избранные труды по семиотике и истории культуры. Т.1. М.: Языки русской культуры, 1999. С. 381-604.

3. Касевич В.Б. Когнитивная лингвистика. В поисках идентичности. Москва, 2013.

4. Кибрик А.А. Когнитивные исследования по дискурсу. Вопросы языкознания. 1994. № 5. С. 126-139.

5. Кубрякова Е.С. Начальные этапы становления когнитивизма: лингвистика - психология - когнитивная наука. Вопросы языкознания. 1994. № 4.

6. Маслова В.А. Когнитивная лингвистика: учебное пособие. Минск: Тетра системе, 2008. 272 с.

7. Скребцова Т.Г. Американская школа когнитивной лингвистики. Санкт - Петербург: Анатомия, 2000.

8. Цепцов В.А. От критики коннекционизма к гибридным системам обработки информации. Познание. Общество. Развитие . Москва , 1996.С. 136-148.

9. Черниговская Т.В. Чеширская улыбка кота Шрёдингера: язык и сознание. Москва: Языки славянской культуры , 2013.448 с.

10. Chomsky N. Aspects of the Theory of Syntax. Cambridge (MA), 1965.

11. Bickerton D. Language Evolution: a Brief Guide for Linguists. Lingua. 2007. № 117(3).

12. Fauconnier G., Turner M. The Way we Think: Conceptual Blending in the Mind Hidden Complexes. New York, 2008.

13. Fitch W.T., Hauser M.D., Chomsky N. The Evolution of the Language Faculty. Clarifications and Implications. Cognition. 2005. 97(2).

14. Fodor G. The Mind doesn't Work that Way: The Scope and Limits of Computational Psychology. Camb. (MA), 2001.

15. Jackendoff R . Semantics and Cognition. Cam. (Man /1993).

16. Langacker R.W. Foundations of Cognitive Grammar. Vol. 1. Theoretical Prerequisites. Stanford, 1987.

17. Miller .G.A., Johnson - Laird P.N. Language and Perception. Cam (Mass), 1976. 
18. Rosch E. Natural Categories. Cognitive Psychology. 1973. № 4.

19. Rosch E. Principles of Categorisation. Cognitive and Categorization. Hillsdals, 1978. P. 27-48.

\section{Information about authors:} Mizetska V. Y., Doctor of Philology Sciences, Professor, Head of the Foreign Languages Department International Humanitarian University 33, Fountain street, Odessa, 65009, Ukraine Zubov M. I., Doctor of Philology Sciences, Professor at the Department of Germanic and Oriental Languages International Humanitarian University 33, Fountain street, Odessa, 65009, Ukraine 